\title{
いわゆる頸部血液囊胞の一症例
}

\author{
西平 茂樹・山内 博幸
}

\section{A Case Report of So-Called Cervical Blood Cyst}

Shigeki Nishihira and Hiroyuki Yamauchi

(Okachi Chuo Hospital)

An eight-year-old boy with a dark red color fluid containing cyst adjacent to the internal jugular vein beneath the carotid sheath is reported. He had had no operations or trauma on his neck before. Pathological examination of the cyst wall revealed its origin to be a medium-size vein. Although we could not find the term "cervical blood cyst" in the current classification of head and neck tumors, we found the term used in the Japanese literature before 1970 .

Key words: cervical blood cyst, CT, MRI, carotid sheath

はじめに

血液霊胞とは, 静脈と直接交通した流動性静 脈血を内容とする賈胞, あるいは血管との関係 が失われ凝血や血性液などの変性血液を内容と する囊胞の総称で, 1814年に W Hey が初めて 報告して以来, また本邦では，1904年に小島が 報告して以来, 1970年後半までの頸部腫瘤の分 類別統計1) 4) や報告5) 8) では稀な疾患として扱 われていた．最近の分類統計報告9) 12) にはそ の名称を見出し得ないが, 著者らは, 最近, 右 側頸部に発生した襄胞性疾患がその頸部血液囊 胞に合致すると思われた 8 歳男子の 1 症例を経 験したので若干の考察を加えて報告する.

\section{症例}

患者 : , 8 歳, 男子.

主訴：右側頸部腫瘤, 圧痛.

現病歴: 1991年 7 月 4 日右側頸部痛出現. そ の 2 日後より同部に腫脹があるのに気付いた。

7 月 9 日近医受診. MRI 検査にて側頸部䛚胞
を疑われ，当科に紹介された. 以前に同部分の 外傷や穿刺等の医療行為を受けたことはない.

局所所見および経過 : 初診時（腫瘤発生後よ り 8 日目), 右側頸部胸鎖乳突筋のほぼ中央裏 面に母指頭大の腫瘤が存在 (図 1 ). ごく軽度 の圧痛は有るが皮膚に炎症所見なし，バルサル

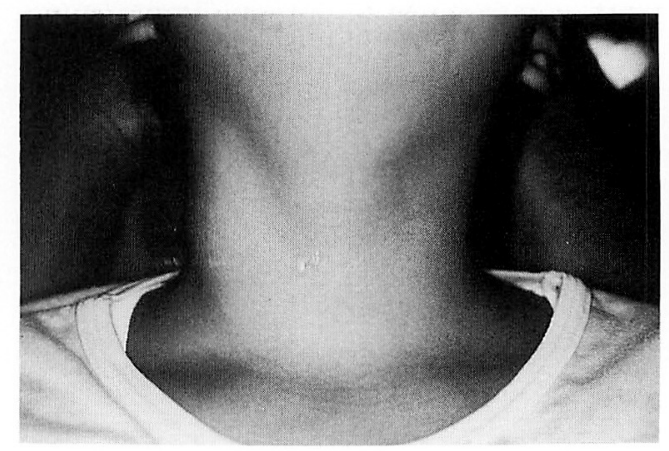

図 1 初診時頸部所見 右側頸部, 胸鎖乳突笳ほぼ中央部に軽度の膨隆を 認める。 
バにて大ささに変化なし．胸鎖乳突筋の裏面に 位置していたが，腫瘤の境界は比較的明膫で， 弾性軟に感じられた。受診後約10日間の抗生剂, 消炎剂投与により圧痛は消失したものの，腫瘤 はむしろやや増大したように感じられたため，
8 月 8 日手術を施行した。術後経過は順調で7 日目に抜系後退院した. 術後 8 力月後の現在, 特変なし。

CT 所見：胸鎖乳突筋直下に筋組織とほぼ同 等の吸収值を有する境界不明膫な腫瘤陰影が存
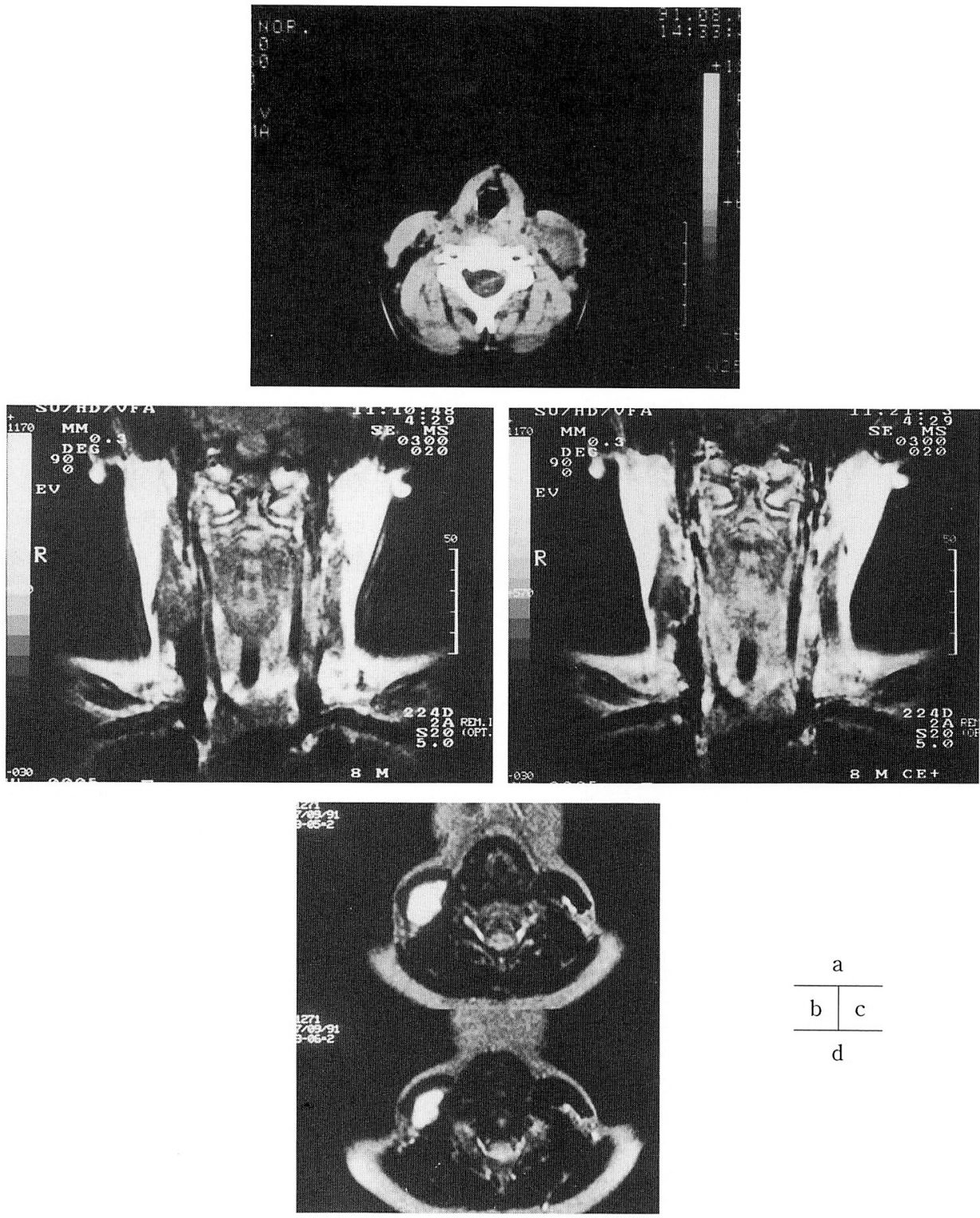

図 2
a ; CT 像
b ; MRI 冠状断 $\mathrm{T}_{1}$ 強調画像
$c ；$ MRI 冠状断 $\mathrm{T}_{1}$ 強調画像（造影後）
$\mathrm{d} ; \mathrm{MRI}$ 水平断 $\mathrm{T}_{2}$ 強調画像 
在する，周囲血管との関係は不明瞭である（図 2 a) .

MRI 所見：腫瘤は胸鎖乳突筋の注ぼ中央に 位置し, 冠状断 T1 強調画像では, 胸鎖乳突筋 と注济同等の信号強度を呈し輪郭は不明瞭であ るが，ガドリニウム DTPA 造影後その輪郭は 明らかとなった。 T2 強調画像では強度の高信 号を示す円形腫瘤として描出されており（図2 b，c), 内頸静脈に接して存在する囊胞性腫瘤 であろらと考兄られたが，水平断像で一般に経 験される側頸囊胞のような円形岁るいは類円形 でなく，内頸静脈を多少内前方に圧排してはい るものの腫瘤内側面が腫瘤内面に凸のカーブを 描き，且つ胸鎖乳突筋との間で前方が扁平にお し潰されたような特殊な形状をしている（図 2
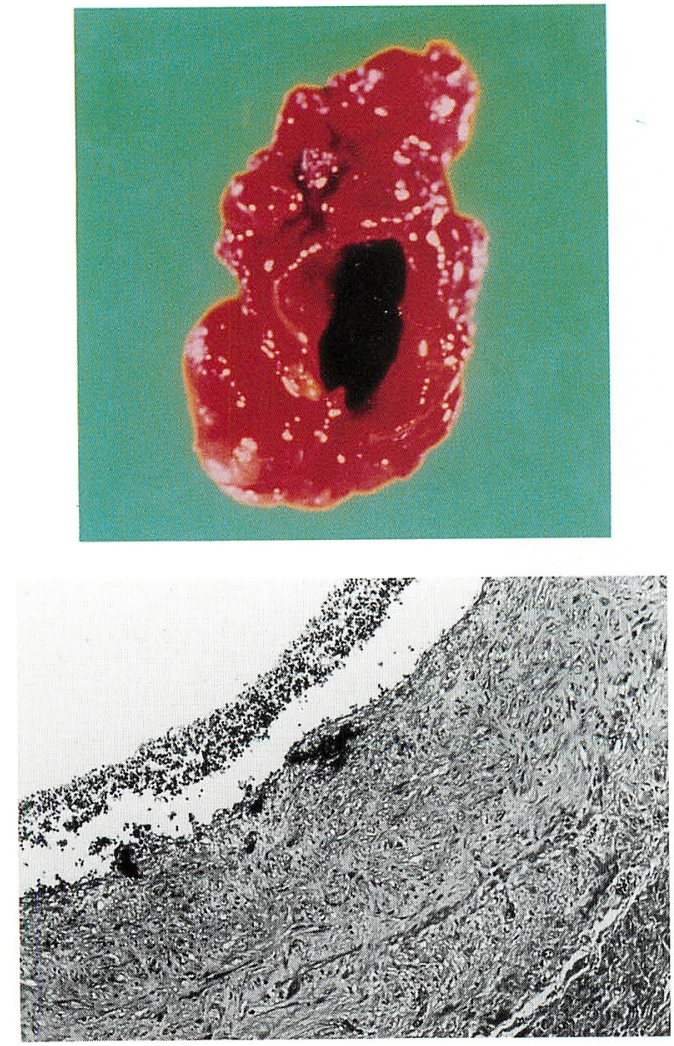

図 3 黄白色の被膜を有し, 内腔には暗赤色の液 体が充满。
上; 摘出標本
下 ; 病理組織像

d).

手術所見：全身麻酔下に，腫瘤直上で約 5 $\mathrm{cm}$ の皮膚横切開を置き, 広頸筋直下を剥離, 胸鎖乳突筋前縁よりアプローチした．腫瘤の前 面から外側面は胸鎖乳突筋と癒着していたため 癒着部分は腫瘍に付着させて切除した。腫瘤は 頸動脈鞘内に存在し, 内側面は内頸動脈々接し ていたが，汪とんど瘉着なく剝離することがで きた。内頸静脈と腫瘤間に明らかな血管の交通 は認められなかった。腫瘤内側に内頸静脈, 迷 走神経，総頸動脈をそれぞれ確認した。腫瘍は， 約 $30 \times 20 \times 25 \mathrm{~mm}$ 大の小さなもので, 黄白色 の被膜を有し，内腔には暗赤色の液体が充満し ていた（図 3 上）。

病理組織所見：囊胞内腔には赤血球が多数認 められた。囊胞壁の内層では単層の扁平な内皮 細胞が所々に残存して認められた。中層では多 少の乱れは㐫ったがほぼ輪状に配列する平滑筋 線維とその間に存在する多量の結合組織が観察 され，さらにその外側では疎性結合組織中に拡 張した毛細管が認められた。すなわち, 囊胞壁 は注涪中等大の静脈壁の構成を示すものであり， 静脈由来の囊胞性疾患と診断された（図 3 下）.

\section{考察}

ここに報告した症例は，従来血液囊胞と呼ば れてきた疾患群に属するものと考光られる，静 脈系の病変に関する記載は，成書でも少なく， 欧米でも静脈拡張症や静脈瘤を扱っているのみ であるが，本邦の文献にはここ十数年前まで血 液䨢胞の存在が記されている。最近出版された （1991年）新外科学大系 ${ }^{13)}$ には症例の供覧抏よ び分類がなされているが，詳細についての記載 はない。これまで報告された血液囊胞に関して まとめてみた。

\section{1. 発生頻度特よび分類}

1973年～1977年の 5 年間に千葉大学第一外科

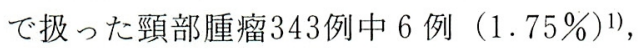
1978年度の昭和大学耳鼻咽喉科外来に括ける頸

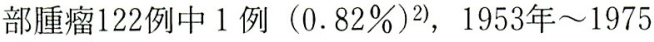
年の 23 年間に信州大学第二外科で扱った頸部腫 
瘤3054例中 3 例 $(0.001 \%)$ ，頸部慗胞性腫瘤82 例中 $0.04 \% 3{ }^{3)}, 1958$ 年 1971 年の 13 年間に慶大 外科で扱った頸部腫瘤284例中 8 例 $(0.03 \%)$, 頸部囊胞性腫瘤87例中 $0.1 \%$ に $^{4)}$ 頸部血液辢胞 症例の統計報告が有る. 分類の範疇としては, 先天性奇形々の他 ${ }^{1)}$ に分類したもの, 脈管由来 の先天性あるいは炎症性疾患として，血管腫や リンパ管種と同様に分類したもの ${ }^{13)}$, 頸部垶胞 性腫瘤の中の一つとして分類したもの ${ }^{344) ， か ゙ ~}$ ある。

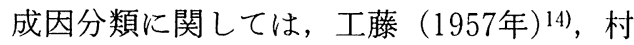
上（1966年)7) が検討を行っている．村上は 1966年までに本邦で報告された血液霊胞34例に 自験例 4 例を加えた40例をもとに，それまで用 いられてきた Spannaus 分類にかわる新分類を 唱えた（表 1 ）。
2. 好発部位・発症年齢・性別その他

伊藤 ${ }^{1)}$ は，小児の胸鎖乳突筋内側部に認めら れ，大きくなると外側頸三角より鎖骨上窩に及 ぶことがあると記載している．松浦は13)，左上 頸部で胸鎖乳突筋表層の筋膜下に存在した12歳 男子の症例を供覧している．児島6) の本邦にお ける22症例のまとめによると，その発生に好発 年跘は認められず，性別では，記載のあった 20 症例中男性 7 例, 女性13例で若干女性に多く, 発生側は左側が右側より多い，好発部位は，側 頸部，鎖骨上窩，前頸部であり，大きいもので は一部腋窩, 一部上胸部に及んでいる，静脈と 交通していたものでは外頸静脈11例, 内頸静脈 6 例. 腫瘤の形状は一定せず, 単房性, 多房性 の両者が有り，大きさは母指頭大から鵎卵大， 鵟卵大, 手挙大と様々である.

表 1 Spannaus の成因分類

A）真性血液翼胞；静脈そのものの異常によって生じるもの

第 1 型：静脈の胎生期形成不全によるもの（頸部の比較的大きな静脈が久如し，そ の位置に血液裂胞があるもの)

第 2 型 : 静脈瘤性㧪張によるもの（血液翼胞と発生血管との間になお交通のあるも のと既に交通のないものとがある)

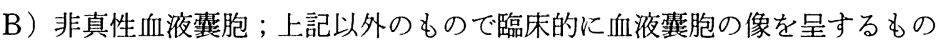

第 3 型：鰓弓䨢胞より発生するもの

第 4 型：血管腫より発生するもの

第 5 型：リンパ管腫より発生するもの

第 6 型：胎生期リンハ腺奇形により発生するもの

村上の新分類

A）真性血液裂胞；脈系の異常によって発生するもの

第 1 型：胎生期の形成不全により，あるいは出生後の静脈瘤性拡張により発生する もの. 発生血管との間の交通の有無によらない.

[Spannaus 分類の第 1 型，第 2 型を含む]

B）偽血液慗胞; 上記以外のすべての血液裂胞を含める.

第 2 型：鰓弓敬胞上り発生するもの

第 3 型：血管腫より発生するもの

第 4 型：リンパ系の異常によって発生するもの

[Spannaus 分類の第 5 型，第 6 型を含む〕

第 5 型：そのほかの血液裂胞，ほとんど全部は後天的な原因によって発生するもの であり，基礎疾患は外傷，腫瘍，炎症等。 


\section{3. 組織学的特徵}

Spannaus や村上の分類に見るように, 非真 性あるいは偽性のものではその基礎となる病変 の病理組織学的特徴を有するものと考光られる が，実際にその記載があるもの7) は少ない，真 性のものは, 基本的に静脈壁の構造を有し, 内 腔に血液を貯留している6) 8).

IfI液贅胞という名称の問題点 : 先に述べたよ らに, 1970年代後半以降の頭頸部の腫瘤性疾患 分類では松浦の記載13) 以外に血液蛪胞といら 名称は見出し得ない，その理由に関しては，推 論の域を出ないが，先ず, Sppannaus 分類, 村上分類のいずれもが包括的すぎて実用的でな かった事があげられる. 非真性あるいは偽性血 液翼胞に関しては, 現在では, それぞれが既に 独立した疾患として扱われて拈り，鰓弓由来の 慗胞, 血管腫, リンパ管種, 他の腫瘍それぞれ の内部で出血し, 血液囊胞の形態を呈したとし ても，原疾患の名称をそのまま用いた方が混乱 が少ない，あえて臨床診断名を血液濾胞とする 必要はなく, 恐らく徐々に使用されなくなって きたものと考兄られた.

真性血液霊胞に関しては, 多少議論の余地が ある.1969年, 田代ら ${ }^{15)}$ が内頸静脈の静脈瘤 性拡張をきたした症例を内頸静脈瘤として報告， 血液翼胞とは異なるものであると考察したが, 翌年, 北ら ${ }^{8)}$ は同様の症例を真性血液囊胞 〔Spannaus 分類A) の第 2 型あるいは村上分 類A）の第 1 型に相当する〕と報告し, 内頸静 脈の限局性拡張すなわち内頸静脈瘤は真性血液 囊胞であると解釈している．1975年には荒井 ら16) が内頸静脈の一部が息をつめることで膨 隆する症例を内頸静脈の奇形として報告, 1979 年には丸山ら ${ }^{17)}$ が内頸静脈拡張症 (internal jugular phlebectasis) として 5 症例を報告し， 1980年には, 小林ら ${ }^{9)}$ が特発性内頸静脈拡張症 として報告している. Spannaus や村上の分類 による真性血液襄胞は, “静脈そのものの, あ るいは静脈系の異常により静脈瘤性拡張が生じ たもの”であるが，内頸静脈拡張の原因として，
Pataro ら（1961年）は, 静脈壁に弾力線維の 消失と結合組織の増生を認めることから壁との ものの病変が原因 ${ }^{18)}$ であるとし，丸山らは， 頸動脈鞘の先天性あるいは後天性の菲薄脆弱化 が関与して扣り，静脈壁そのものの菲薄化は繰 り返し起こる膨出による二次的変化によるも の17) と唱えた. 従って, Pataro らの説では内 頸静脈拡張症は真性血液囊胞の定義の範疇に含 まれる事になるが，丸山の説では別の疾患とい らことになる。確かに，村上ら ${ }^{7)}$ や児島ら ${ }^{6)} の$ まとめに2る真性血液囊胞の症例の中には, 内 頸静脈や外頸静脈と交通する血液霬胞の報告が 成されていたが, 内頸静脈そのものが拡張した ものは含まれておらず，Spannaus および村上 の分類の基礎に内頸静脈そのものの拡張した症 例は含まれていなかったものと考兄られた．現 在, 内頸静脈拡張症は既に一つの独立した疾患 として扱われている．その原因についても明ら かでなく，ここで真性血液囊胞か否かをあらた めて論ずる意義は少ないと考える.

内頸静脈以外の静脈性の膨隆に関しては, 外 国では Lipshutzら (1960年) ${ }^{19)}$, Derrickら (1962年) ${ }^{20)}$, Alonso ら (1970年) ${ }^{21)}$ が外頸静脈 で，1972年に Wadley ら 22) が後顔面静脈で, 1972年には Gilbert ら23) が前頸動脈で経験し， 静脈拡張症あるいは静脈瘤として報告している。 本邦では，先に記したように，内頸静脈や外頸 静脈あるいは鎖骨下静脈と交通した腫瘤や，発 生血管との交通は失われているが病理組織学的 に壁が静脈あるいはその類似構造を示寸静脈由

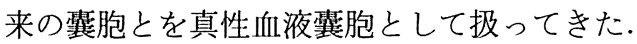
今回我々が経験した症例は，定義上は発生血管 との交通が既に失われた真性血液囊胞と考号ら れるが，現在の頸部腫瘤分類では先天性奇形そ の他, あるいは分類不能の頸部囊胞性腫留とし て扱わざるを得ない、今後, 同様症例の蓄積を まって総括的な検討がなされるものと期待する.

4. 画像診断についての考察

本症例では, 当初, MRI 所見が普通に経験 される側頸晸胞のように円形あるいは類円形で 
なく，いびつな形をしている事に疑問を持った が，非常に柔らかく且つ小さな整胞のためであ ろらかと考光ていた，手術により，霊胞が頸動 脈鞘内に存在したことから，また，病理組織所 見から，今回の検索が始まったわけであるが， 術前に裂胞と頸動脈鞘との関係を考察しておれ ば，一般に見られる側頸部襄胞とは異なるもの であろらとの予測がたてられたかも知れない。 頸動脈鞘は2425)，頭蓋底から縦隔に至る線維性 の鞘で, pretrachal fascia と prevertebral fascia によって形成され, 内頸動脈, 総頸動脈, 内頸静脈, 迷走神経, 頸神経ワナの一部, 頸部 交感神経幹を囲んでおり，頸動脈分岐部上り下 のレベルではっきりした鞘として確認され，い わゆる carotid space を形成寸る。鞘はかなり 厚く強固であり，簡単な鉗子操作で破れるほど 脆弱ではない17) 。内頸動脈分岐部より上方で は, 䩗は内頸静脈や内頸動脈に密着して存在す るため，いわゆる頸動脈鞘に囲まれた carotid space を形成せず, poststyloid space, retrostyloid space あるいは posterior or neurovascular component of the parapharyngeal space と称され，それぞれの component は疎 な結合組織で隔てられるのみとなる26)。今回の 症例の場合，第 2 鰓溝由来の襄胞との鑑別が最 も重要と考兄られる．発生学的に第 2 鰓溝由来 の側頸部翼胞の頸部への進展は, 頸動脈分岐部 より上方から側頸部に下降する経路をとる27)28) ため，頸動脈鞘外に存在することになる．従っ $\tau$ ，側頸部囊胞 Bailey 分類 III 型以外の症例で は，薱胞の発育を妨げるものがないため疎な結 合組織で隔てられた周囲器官を均等に圧排して 水平断画像上円形 類円形の腫瘤として描出さ れると考兄いる．本症例では頸動脈鞘といら 障壁の張力29) が加わった分，一般に経験され る側頸部埕胞と異なる，いびつな形状になった ものと推察された。本褧胞は，たまたま頸動脈 鞘内に発生したものであろらが，これまで画像 診断に際して頸動脈鞘の存在を意識することが なかった著者にとっては印象深い所見であった。
おわりに

8 歳男子の側頸部に発生した静脈由来の囊胞 について報告した。文献検索の結果従来頸部血 液整胞と称されていた疾患群が最も類似するも のであった。

\section{参考文献}

1）伊藤健次郎：頸部腫瘤の臨床診断. 外科 Mook $7: 1 \sim 14,1979$.

2）寉田哲昭：頸部腫䀶における悪性腫愓と openbiopsy の適否. 耳鼻 $25: 1316 \sim 1318,1979$.

3）黑田孝井, 川村信之, 宮川 信, 他：頸部腫瘤, とくに頸部翼胞性腫瘤の病態ならびに治療. 外 科治療 $38: 11 \sim 16,1978$.

4）植草 稔, 米山桂八, 三村 孝, 他 : 頸部腫瘤 の臨床診断. 外科診療 $9: 1123 \sim 1129,1971$.

5）沢田 啓：側頸部血液裂胞の 1 例. 臨床外科 $7: 466 \sim 468,1952$.

6）児島 保：頸部血液狦胞の 1 例. 外科の領域 $7: 1228 \sim 1231,1959$.

7）村上国男, 上野 明, 菱田泰治, 他: 頸部血液 翼胞 一新分類法の提唱一. 外科 $28: 163 \sim 169$, 1966.

8）北 陸平, 三崎英生 : 頸部真性血液翼胞の 1 例. 外科 $32: 1087 \sim 1089,1970$.

9）小林武夫, 本多清志, 山本英史 : 頸部のコンピ ューター断層撮影. 耳展 $52: 1013 \sim 1018,1980$.

10）高橋広臣 : 頸部腫瘤をきたす疾患の種類・頻度. 臨外 $42: 433 \sim 438,1987$.

11）金子まどか，古川 滋，高畑喜廷，他：当科に おける頸部腫溜の検討。耳鼻 $35 ： 179 \sim 188$, 1989.

12）林崎勝武: 頸部腫瘍の臨床. 外科治療 $65 ： 127$ $\sim 132,1991$.

13）松浦秀博：頸部腫場および類似疾患, 頭頸部の 外科. 新外科体系 第 14 巻 (和田達雄監修). 287 ３11頁, 中山書店, 東京, 1991 .

14）工藤達之：頸部血液琵胞. 日本外科全書 13 : 235 256, 1957.

15）田代豊一, 谷川清一, 坂本英明, 他 : 内頸静脈 瘤の 1 手術治験例. 手術 22：658～660, 1969.

16）荒井和夫, 末光迪生, 関 伸二, 他 : 内頸静脈 奇形の一例. 耳展 $18: 275 \sim 278,1975$.

17）丸山 毅, 村上 泰：小児内頸静脈执張症. 日 
耳鼻 $82 ： 1361 \sim 1364,1979$

18) Pataro, VF, Crosbie JC and Conde RM : Jugular phleb ectasia. J Cardiovasc Surg $2: 3$ $\sim 8,1961$.

19) Lipshutz $\mathrm{SN}$ and Rubin $\mathrm{MH}$ : External jugular phlebectasia. Arch Surg $80: 571 \sim 573,1960$.

20) Derrick JR and Spencer DC : Localized cervical venectasia, presented as a neck tumor. Am J Surg 103 : 521 522, 1962.

21) Alonso WA and Chambers RG: Aberrant jugular vein simulating a cervical cyst. Laryngoscope $80: 244 \sim 248,1970$.

22) Wadley JK : Aneurysm of the posterior facial vein. Laryngoscope $82: 821 \sim 823,1972$.

23) Gilbert MG, Greenberg LA, Brown WT, et al : Fusiform aneurysm of the neck in children; report of four cases. J Pediatr Surg $7: 106 \sim$ 111, 1972.

24) Davies DV and Coupland RE : Myology fasciae and muscles of the neck. Gray's anatomy 34 edition (ed by DV Davies), pp 605,
Longmans, London, 1972.

25) Som PM : The pharynx and oral cavity. "Carotid space" Head and Neck Imaging (ed by Som PM and Bergron RT). pp419, Mosby Year Book, St Louis, Missouri, 1991.

26) Som PM : The Neck. "Non nodal pathologic conditions of the neck" Head and Neck Imaging (ed by Som PM and Bergron RT). pp 531 557, Mosby Year Book, St Louis, Missouri, 1991.

27）高橋廣臣 : 先天性頸部腫脹. 耳喉 55 : 847 856, 1983.

28）西條 茂: 側頸部整胞. JOHNS $5: 725 \sim 730$, 1989.

29) Garrow E, Kirschtein $M$ and Som ML : Internal jugular phleb ectasia. Am J Surg $108: 380$ $\sim 383,1964$.

$\left(\begin{array}{l}\text { 別刷請求先 : 西平茂樹 } \\ \text { 干012 湯沢市表町2-3-15 } \\ \text { 秋田県厚生連雄勝中央病院耳鼻咽喉科 }\end{array}\right)$ 